\title{
MAKING THE EUROZONE SUSTAINABLE BY FINANICAL ENGINEERING OR POLITICAL UNION?
}

\author{
Paul De Grauwe, London School of Economics \\ Yuemei Ji, University College London
}

\section{Introduction}

2018 will be the year when policymakers and official institutions in the Eurozone embraced the intellectual idea that financial markets can be used to impose budgetary discipline and that suitably constructed financial assets can promote financial stability in the Eurozone. This idea has become popular among Eurozone policy-makers because of a realization that achieving discipline and stability by political means, such as political integration, has hit a wall preventing any further progress.

During 2018, a group of French and German economists proposed various schemes such as sovereign bankruptcy procedures and triggers that would force governments to issue different tranches of debt in the hope of garnering the disciplining powers of the markets (Bénassy-Quéré, et al. (2018), Lane and Langfield(2018)) ${ }^{1}$. The European Systemic Risk Board (2018) published a report containing a proposal to create a "safe asset" for the Eurozone that is based on a repackaging of the risks of sovereign bonds. The European Commission followed up on this and came forward supporting the idea of creating a safe asset (European Commission(2018)). The hope is that this financial engineering will stabilize an otherwise unstable system of sovereign bond markets in the Eurozone. Thus, during 2018, official policy has become very much based on using market forces to discipline and to stabilize the Eurozone.

In a way all this is quite surprising. One thing we have learned from the financial crisis is that financial markets cannot be trusted as a disciplining device. During the booming years prior to the crisis, euphoria dominated in financial markets leading consumers, banks, firms, and investors to be blind for risk. As a result,

\footnotetext{
${ }^{1}$ For a more general criticism of the French-German reform proposals, see Messori and Micossi(2018))
} 
encouraged by equally euphoric rating agencies, they took up massive amounts of debt disregarding the risks they took on their balance sheets. This was the time financial markets considered Greek sovereign bonds to exhibit the same risk as German sovereign bonds. Financial markets were an engine of indiscipline.

When the crash came, financial markets panicked. Suddenly they detected risks everywhere forcing consumers, firms and governments into excessive austerity thereby deepening the recession (e.g. Eurozone sovereign debt crisis see De Grauwe and Ji(2013)). Financial markets became engines of excessive discipline.

All this is not new. Economic historians (Kindleberger(1978), Minsky(1986)) have taught us for some time that financial markets almost never apply the right amount of discipline (see also Lo(2012)). During booms markets apply too little discipline thereby amplifying the boom and during recessions they impose too much discipline thereby making the downturn worse.

In this article we discuss the recent proposals that aim at garnering financial markets to discipline and stabilize the Eurozone, and we analyze whether the financial engineering that is implicit in these proposals will help to stabilize the Eurozone. We will argue that financial engineering cannot stabilize a financial system that is fundamentally unstable. Our conclusion will be that further steps towards political integration are key in making the Eurozone sustainable in the long run.

\section{Government bond markets in the Eurozone are unstable}

Let us first describe the nature of the instability of the government bond markets in a monetary union (see De Grauwe(2011), and De Grauwe and Ji(2013)). We then analyze whether these proposals will succeed in stabilizing government bond markets in the Eurozone in section 3 and 4.

The instability of the sovereign bond markets in the Eurozone can be described as follows. National governments in a monetary union issue debt in a currency that is not their own, but is equivalent to a foreign currency. As a result of this lack of control over the currency in which the bonds are issued, these 
governments cannot guarantee that the bondholders will always be paid out at maturity. This contrasts with governments of countries issuing their own currency. These governments can give a full guarantee to the bondholders because they know that the central bank stands ready to provide liquidity in times of crisis. All this leads to a situation in which government bond markets in a monetary union can be hit by self-fulfilling crises: investors distrusting the capacity (or willingness) of a government to continue to service its debt, sell the bonds thereby raising the yields and making it more difficult for that government to rollover its debt. A liquidity crisis erupts which results from a fear that the government will be hit by a liquidity crisis. This usually happens during recessions when budget deficits and government debts increase automatically. Investors will then single out those governments perceived to be most at risk, sell their bonds, and acquire bonds issued by governments perceived to be less risky. As a result, massive capital flows across the borders of the monetary union are set in motion destabilizing the whole system. This is exactly what happened during the sovereign debt crisis of 2010-12.

The instability of the government bond markets in a monetary union is aggravated by a possible doom loop between the banks and the sovereign. When banks are in trouble, the sovereign who is obliged to save the banks will also be hit by a liquidity and possibly a solvency crisis. This was the problem of Ireland. The reverse can also happen: a sovereign debt crisis leads domestic banks, holding large amounts of domestic sovereign bonds, into illiquidity and insolvency (the Greek problem). The doom loop amplifies a sovereign debt crisis. That does not mean though that sovereign debt crises and the ensuing destabilizing capital flows cannot erupt in the absence of a banking crisis.

Let us now turn to the proposals mentioned earlier.

\section{Introducing market discipline}

In this section we concentrate on two proposals that aim at enforcing market discipline by financial engineering. The first one proposes to change the existing structural budget balance rule by an expenditure rule that, if exceeded, would 
force governments to issue junior debt. The second proposal wants to enforce sovereign debt default procedures on governments that have become insolvent. Let us discuss these consecutively.

\subsection{Tranching government debt}

The idea behind the proposal to force governments to issue junior debt if their expenditures exceed some threshold value is that this will subject governments to more market discipline. The reasoning is the following. When governments spend too much they are forced to finance the extra spending by issuing junior bonds. As a result, the buyers of these bonds will face more risk and demand a risk premium. Thus these governments will pay a higher interest rate which will enforce more discipline. The market will do its job of raining in the tendency of governments to spend too much.

All this sounds plausible. The evidence of past financial cycles of booms and busts, however, is that this disciplining mechanism typically fails. During booms, euphoria prevails and few investors perceive risks. As mentioned earlier, during the Eurozone boom years, investor saw no difference in risks between Greek and German sovereign bonds. It is likely that when euphoria prevails they will see no significant difference in risks between the different tranches of outstanding government bonds.

During the downturn exactly the opposite will happen. In fact the existence of junior bonds will work as wake-up call and set in motion panic reactions of flight. As a result, governments, which have issued junior bonds, are more likely to be hit by a self-fulfilling liquidity crisis forcing them into excessive discipline and austerity.

The reality is that financial markets are not well-equipped to enforce discipline on sovereigns. The introduction of some new financial instrument will not change that reality.

\subsection{Sovereign default procedures}

The second proposal aiming at using market forces to discipline governments uses a formal sovereign debt restructuring procedure. Governments that are insolvent should be forced to restructure their debt. In other words the holders 
of these governments' bonds should be forced to accept losses. As a result, investors would realize that, without a possible bailout of the sovereign, their investments would be risky. This would lead them to ask for a risk premium, thereby introducing market discipline on the behavior of the sovereign.

Again, at first sight this sounds reasonable. The same criticism, however, applies here to the one we leveled against the forced issue of junior bonds. There is very little evidence that investors ask for risk premia during boom phases. That's when euphoria blinds them in not seeing risks properly. And during the bust phase the opposite occurs. That's when the knowledge of the existence of debt restructuring procedures will act as triggers that create fear and panic. As a result, the existence of a sovereign restructuring procedure may actually trigger crises more easily during the bust.

There is an additional problem with this proposal. This has to do with identifying when governments are insolvent. It is easy to say that an insolvent sovereign should be forced to restructure his debt. It is much more difficult, during crises moments, to distinguish between solvency and liquidity problems of sovereigns. This difficulty arose during the sovereign debt crisis of 2010-12. In the case of Greece it was relatively easy to conclude that the Greek government was insolvent. But what about countries like Ireland, Spain, and Portugal? These countries were gripped by massive sales of their sovereign bonds leading to a liquidity crunch that made it impossible to rollover their debt at normal market conditions. Quite a lot of economists concluded that these countries were insolvent and should restructure their debt. It turned out that this advice was wrong and that these countries were solvent but had become illiquid. Had they been forced to restructure their debt, economic recovery would have been much more difficult.

\section{The safe asset proposal}

The proposal to create a safe asset in the Eurozone, which was made by the ESRB, explicitly aims at eliminating the destabilizing capital flows across the 
borders of the monetary union and to stabilize the system. Will it do this? This is the question we now turn to.

In contrast with earlier proposals to create Eurobonds (see De Grauwe and Moesen(2009), and Delpla and von Weizsäcker(2010)) which assume that participating governments are jointly liable for the service of the national debts, the "safe asset" proposal makes no assumption of joint liability. Instead, in this proposal national governments are individually liable for their own debt. There is no pooling of risks.

The "safe asset" is created when financial institutions (private or public) buy a portfolio of national government bonds (in the primary or in the secondary markets) and use this portfolio as a backing for their own issue of bonds, called "sovereign bond backed securities" (SBBS). The latter have the following characteristics. One tranche, the junior tranche, is risky. When losses are posted on the underlying portfolio of government bonds the junior tranche takes the hit $^{2}$. The second tranche, the senior tranche, is safe. The proponents of these SBBSs take the view that a $30 \%$ junior tranche is large enough as a buffer to take potential losses on the underlying sovereign bonds so as to make the senior tranche $(70 \%)$ risk free. Based on simulations of underlying risk patterns, the authors claim that their proposal will allow to more than double the size of safe assets in the Eurozone. In addition, they claim that the existence of SBBSs will replace the destabilizing capital flows across national borders in the Eurozone by a movement from the risky asset (the junior tranche) into the safe asset (the senior tranche), thereby eliminating the instability in the Eurozone.

How likely is it that these SBBSs will help to stabilize the Eurozone? Note that in the way we formulate the question we do not dispute that in normal times the creation of a safe asset may not increase the efficiency of the financial system in the Eurozone. It probably will do so by supplying a new type of asset that can provide for a better diversification of normal risks. The issue is whether the safe

${ }^{2}$ In the ESRB(2018) proposal this tranche is split further into two tranches, a junior tranche proper with the highest risk (10\%) and a mezzanine tranche $(20 \%)$ which takes the losses after the junior tranche has been depleted. 
asset will be an instrument for dealing with systemic risks in times of crisis? Our answer is negative for the following reasons.

First, the creation of a safe asset does not eliminate the national government bond markets. This is recognized by the proponents of a safe asset (see $\operatorname{ESRB(2018)}$ and Brunnermeier, et al.(2016)). In fact these proponents have made the continuing existence of national sovereign bond markets a key component of their proposal. According to the ESRB "the SBBS issuance requires price formation in sovereign bond markets to continue to be efficient" (p.33). The markets for sovereign bonds must remain large enough so as to maintain their liquidity. That is also why the ESRB proposes to limit the total SBBS issuance to at most $33 \%$ of the total outstanding stock of sovereign bonds.

This constraint on the issue of SSBS implies that national sovereign bond markets will be "alive and kicking". As a result, the major problem that we identified earlier, i.e. the potential for destabilizing capital flows across the borders of the monetary union will still be present. However, since the markets of sovereign bonds will have shrunk the yields are likely to be more volatile during crisis periods.

Second, we observe that during crises, the correlation pattern of yields changes dramatically. During normal times all yields are highly positively correlated. During crisis times, as investors are looking for safe havens, the yields in the safe assets tend to decline sharply and become negatively correlated with the high risk yields. This pattern was very pronounced during the sovereign debt crisis of 2010-12. In their simulations of the risks involved in SBBSs Brunnermeier, et al.(2016) do take into account the fact that risks can be correlated. However, this correlation pattern is fixed, while during crisis periods correlation patterns change dramatically. We show this feature in Table 1 . We find that during the sovereign debt crisis of 2010-12, the government bond yields of the periphery countries under stress were highly positively correlated. At the same time these yields were negatively correlated with the yields of the core (safe) countries like (Germany, Finland, France, Netherlands).

The implication is that during crises it is very unlikely that the senior tranche in the SBBS can maintain its status of safe asset. It will consist of bonds investors 
dump and "safe-haven" bonds. The senior tranche will continue to depend on the cash flow generated by bonds that panicking investors deem to be extremely risky. The perception that this senior tranche is equally safe as the safe-haven sovereign bonds (e.g. German bonds) is very unlikely when markets are in panic mode. As a result, it is also likely that investors will flee the senior tranches of the SBBS to invest in the "real thing", i.e. super safe sovereign national bonds.

A third problem is related to the previous one. During normal times, the safe asset will have been used in the pricing of derivatives and other financial instruments and it will be an important part of the repo market providing liquidity in that market. As a result, a large part of the financial markets in the Eurozone will depend on the perceived safety and liquidity of the SBBS construction. When during crisis periods, the safety of that construction is put into doubt (as we argued in the previous section), liquidity will tend to disappear and the whole financial sector of the Eurozone will be at risk. In the end we may have more rather than less financial stability in the Eurozone.

There is an historical analogy here. During the boom years CDOs were created backed by different types of securities, e.g. mortgages. At the time, many people were enthusiastic about this and believed that CDOs would make the financial markets more efficient by a better spreading of risks. Ultimately, it was believed, this would lead to more financial stability. The SBBS proposed by the ESRB has the same CDO structure as the previous ones. It would be surprising that financial engineering, which in the past failed dismally in stabilizing financial markets, would do so in the future.

\section{Conclusion: the inevitability of political union}

We have argued that various proposals made during 2018 aimed at stabilizing the Eurozone by financial engineering do not eliminate the inherent instability of the sovereign bond markets in a monetary union. During crises this instability becomes systemic and no amount of financial engineering can stabilize an otherwise unstable system. 
The proposals made by the French and German economists (Bénassy-Quéré, et al. (2018)) have clearly be inspired by concerns about moral hazard. These concerns are very intense among German economists and have left their mark on the reform proposals of the French-German group of economists. Moral hazard means that agents consciously take too much risk because they expect others to bail them out. It is very unlikely, however, that the sovereign debt crisis had much to do with moral hazard. It stretches the imagination to believe that the Greek, Irish, Portuguese or Spanish governments decided to allow their debt levels to increase in the expectation that they would be bailed out by the governments of Northern Eurozone countries. Our hypothesis that the sovereign debt crisis erupted as a result of a boom that led private and public agents to disregard risk makes more sense. But even if moral hazard was a cause of the crisis, those who took on too much risk will have learned that the punishment for being bailed out by Northern Eurozone governments is severe. It should by now be clear that no government would wish to be bailed out by these governments.

Stabilization by financial engineering will not work. Real stabilization of the Eurozone goes through two mechanisms. The first one is the willingness of the ECB to provide liquidity in the sovereign bond markets of the Eurozone during times of crisis. The ECB has set up its OMT-program to do this. However, OMT is loaded with austerity conditions, which will be counterproductive when used during recessions (which is when crises generally occur). That is why a second mechanism is necessary. This consists in creating Eurobonds that are based on joint liability of the participating national governments. Without such joint liability it will not be possible to create a common sovereign bond market. The creation of such a common bond market makes it possible to eliminate the inherent instability of a monetary union that has centralized money but kept the national government bond markets alive. It is therefore also a conditio sine qua non for long-term stability the Eurozone.

Issuing common Eurobonds presupposes a very intrusive process of political unification with substantial further transfers of sovereignty. The issuer of such common bonds necessarily has to be a European government with the power to tax and to spend. Such a power must be embedded in a democratic decision 
making process involving the European parliament. The political willingness to go in this direction, however, is non-existent today. There is no willingness to provide a common insurance mechanism that would put taxpayers in one country at risk of having to transfer money to other countries. Under those conditions the sovereign bond markets in the Eurozone will continue to be prone to instability.

Although the willingness to create a political union today that is necessary to sustain the euro does not exist, it is important to keep a political momentum alive that this remains necessary for the long-term survival of the Eurozone. Such a momentum can be created by a strategy of small steps (Enderlein, et al. (2012), such as the creation of a limited fiscal space at the level of the Eurozone. Other proposals such as a common unemployment insurance mechanism come to mind as part of a strategy of small steps (Van Rompuy, et al. 2012), Alcidi and Thirion(2015))

With the election of Emmanuel Macron as French president in 2017 there was some hope that such a strategy of small steps could be set in motion. Macron's proposal to create an embryonic government budget for the Eurozone seemed to open the door for such a strategy. The political events of 2018, however, seem to have closed that door for the time being. Macron's proposal was effectively buried during the December 2018 summit meeting of the European heads of state, when it was decided to make it part of the EU budget. This ensured that this budget would remain infinitesimally small for the time being.

The danger of financial engineering proposals is that they create a fiction allowing policymakers to believe that they can achieve the objective of stability by some technical wizardry without having to pay the price of a further transfer of sovereignty. This fiction could become an impediment to taking the necessary steps to further political unification that alone can ensure the sustainability of the Eurozone in the long run. . 


\section{References}

Alcidi, C., and Thirion, G., (2015), Feasibility and Added Value of a European Unemployment Benefit Scheme, Interim Report, CEPS, Brussels

Benassy-Quéré, A., et al. (2018), Reconciling risk sharing with market discipline: A constructive approach to euro area reform, CEPR Policy Insight, no. 91, https://cepr.org/sites/default/files/policy_insights/PolicyInsight91.pdf

Brunnermeier, M. Langfield, S., Pagano, M., Reis, R., Van Nieuwerburgh, S., Vayanos, D., (2016), ESBies: Safety in the tranches, ESRB Working Paper Series, no. 21.

De Grauwe, P., The Governance of a Fragile Eurozone, CEPS Working Documents, Economic Policy, May 2011 http://www.ceps.eu/book/governance-fragileeurozone

De Grauwe, P., and Moesen, W. (2009) 'Gains for All: A Proposal for a Common Eurobond', Intereconomics, May/June.

De Grauwe, P., and Ji, Y., (2013), Self-fulfilling Crises in the Eurozone: An Empirical Test, Journal of International Money and Finance, Volume 34, April, Pages 15-36

Delpla, J., and von Weizsäcker, J., (2010), the Blue Bond Proposal, Bruegel Policy Brief, May.

Enderlein, H., et al., (2012), Completing the Euro. A road map towards fiscal union in Europe, Report of the "Tomaso Padoa-Schioppa Group", Notre Europe, June.

European Commission, 2018, http://europa.eu/rapid/press-release_MEMO-183726_en.htm

European Systemic Risk Board (ESRB), (2018), Sovereign bond-backed securities: a feasibility study; January.

Kindleberger, C. P. (1978). Manias, Panics and Crashes: A History of Financial Crises, Wiley.

Lane, Ph., and Langfeld, S., (2018), The feasibility of sovereing bond backed secutities in the euro area, https://voxeu.org/article/feasibility-sovereignbond-backed-securities-euro-area

Messori, and Micossi, S., (2018), Counterproductive Proposals on Euro Area Reforms by French and German Economists, Centre for European Policy Studies, https://www.ceps.eu/system/files/PI2018_04_MMandSM_PI91.pdf

Minsky, H. (1986). Stabilizing an Unstable Economy. Yale University Press

Tabellini, G. (2017), "Reforming the eurozone: Structuring vs Restructuring Sovereign Debts", Voxeu.org, 23 November.

Van Rompuy, H. in close collaboration with Barroso, J.M., Juncker, J.C., Draghi, M. (2012)., "Towards a Genuine Economic and Monetary Union", European Council, 5 December, Final Report. 
Table 1. Correlation of yields before crisis (2000M1-2009M12)

\begin{tabular}{|c|c|c|c|c|c|c|c|c|c|c|c|}
\hline & Germany & Finland & Netherlands & Austria & France & Belgium & Italy & Spain & Ireland & Portugal & Greece \\
\hline Germany & 1.00 & & & & & & & & & & \\
\hline Finland & 0.97 & 1.00 & & & & & & & & & \\
\hline Netherlands & 0.97 & 1.00 & 1.00 & & & & & & & & \\
\hline Austria & 0.94 & 0.99 & 0.99 & 1.00 & & & & & & & \\
\hline France & 0.98 & 1.00 & 1.00 & 0.99 & 1.00 & & & & & & \\
\hline Belgium & 0.95 & 1.00 & 0.99 & 1.00 & 0.99 & 1.00 & & & & & \\
\hline Italy & 0.89 & 0.97 & 0.96 & 0.99 & 0.96 & 0.98 & 1.00 & & & & \\
\hline Spain & 0.94 & 0.99 & 0.99 & 1.00 & 0.98 & 1.00 & 0.99 & 1.00 & & & \\
\hline Ireland & 0.61 & 0.78 & 0.76 & 0.83 & 0.74 & 0.81 & 0.88 & 0.83 & 1.00 & & \\
\hline Portugal & 0.90 & 0.98 & 0.97 & 0.99 & 0.96 & 0.99 & 0.99 & 0.99 & 0.87 & 1.00 & \\
\hline Greece & 0.68 & 0.83 & 0.82 & 0.87 & 0.80 & 0.86 & 0.92 & 0.88 & 0.96 & 0.91 & 1.00 \\
\hline
\end{tabular}

Table 2. Correlation of yields during crisis (2010M1-2012M09)

\begin{tabular}{|c|c|c|c|c|c|c|c|c|c|c|c|}
\hline & Germany & Finland & Netherlands & Austria & France & Belgium & Italy & Spain & Ireland & Portugal & Greece \\
\hline Germany & 1.00 & & & & & & & & & & \\
\hline Finland & 0.98 & 1.00 & & & & & & & & & \\
\hline Netherlands & 0.99 & 0.99 & 1.00 & & & & & & & & \\
\hline Austria & 0.89 & 0.93 & 0.91 & 1.00 & & & & & & & \\
\hline France & 0.83 & 0.89 & 0.87 & 0.98 & 1.00 & & & & & & \\
\hline Belgium & 0.45 & 0.58 & 0.54 & 0.74 & 0.80 & 1.00 & & & & & \\
\hline Italy & -0.66 & -0.57 & -0.58 & -0.34 & -0.21 & 0.28 & 1.00 & & & & \\
\hline Spain & -0.62 & -0.60 & -0.55 & -0.48 & -0.34 & 0.02 & 0.81 & 1.00 & & & \\
\hline Ireland & 0.16 & 0.24 & 0.24 & 0.28 & 0.38 & 0.68 & 0.38 & 0.44 & 1.00 & & \\
\hline Portugal & -0.62 & -0.52 & -0.54 & -0.32 & -0.19 & 0.29 & 0.88 & 0.73 & 0.54 & 1.00 & \\
\hline Greece & -0.82 & -0.79 & -0.78 & -0.62 & -0.50 & -0.13 & 0.81 & 0.81 & 0.23 & 0.85 & 1.00 \\
\hline
\end{tabular}

Table 3. Correlation of yields after crisis (2012M10-2017M12)

\begin{tabular}{|c|c|c|c|c|c|c|c|c|c|c|c|}
\hline & Germany & Finland & Netherlands & Austria & France & Belgium & Italy & Spain & Ireland & Portugal & Greece \\
\hline Germany & 1.00 & & & & & & & & & & \\
\hline Finland & 1.00 & 1.00 & & & & & & & & & \\
\hline Netherlands & 1.00 & 1.00 & 1.00 & & & & & & & & \\
\hline Austria & 1.00 & 0.99 & 1.00 & 1.00 & & & & & & & \\
\hline France & 0.99 & 0.99 & 0.99 & 0.99 & 1.00 & & & & & & \\
\hline Belgium & 0.99 & 0.99 & 0.99 & 0.99 & 0.99 & 1.00 & & & & & \\
\hline Italy & 0.92 & 0.91 & 0.92 & 0.93 & 0.95 & 0.95 & 1.00 & & & & \\
\hline Spain & 0.90 & 0.90 & 0.90 & 0.92 & 0.92 & 0.94 & 0.97 & 1.00 & & & \\
\hline Ireland & 0.93 & 0.93 & 0.93 & 0.95 & 0.95 & 0.96 & 0.97 & 0.99 & 1.00 & & \\
\hline Portugal & 0.78 & 0.78 & 0.79 & 0.82 & 0.83 & 0.85 & 0.93 & 0.93 & 0.92 & 1.00 & \\
\hline Greece & 0.31 & 0.31 & 0.31 & 0.35 & 0.34 & 0.38 & 0.45 & 0.58 & 0.55 & 0.57 & 1.00 \\
\hline
\end{tabular}

Source: European Central Bank and authors' own calculation

Note: The yields are yields on 10-year government bonds 